\title{
ACMONIDESITE, A NEW AMMONIUM SULFATE CHLORIDE FROM LA FOSSA CRATER, VULCANO, AEOLIAN ISLANDS, ITALY
}

\section{Francesco Demartin, Carlo Castellano and Italo Campostrini}

Università degli Studi di Milano, Dipartimento di Chimica, via Golgi 19, I-20133 Milano, Italy.

E-mail:francesco.demartin@unimi.it

[Received 22 December 2017; Accepted 7 February 2018; Associate Editor: Giancarlo Della Ventura]

\section{AbStract}

The new mineral acmonidesite, $\left(\mathrm{NH}_{4}, \mathrm{~K}, \mathrm{~Pb}^{2+}, \mathrm{Na}\right)_{9} \mathrm{Fe}_{4}{ }^{2+}\left(\mathrm{SO}_{4}\right)_{5} \mathrm{Cl}_{8}$, was found in an active fumarole (fumarole FA, temperature about $250{ }^{\circ} \mathrm{C}$ ) at La Fossa crater, Vulcano, Aeolian Islands, Sicily, Italy. It occurs on a pyroclastic breccia as brown prismatic crystals up to $0.10 \mathrm{~mm}$ in length, in association with salammoniac, alunite and adranosite. The mineral is orthorhombic, space group: $C 222_{1}$ (no. 20) with $a=9.841(1), b=19.448(3) c=17.847(3) \AA, V=3415.7(9) \AA^{3}$ and $Z=4$. The

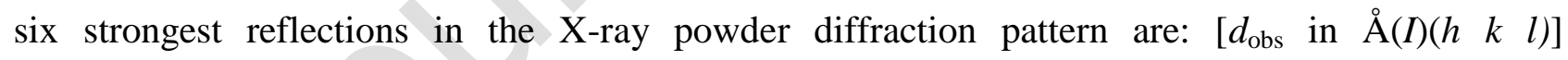
8.766(100)(1 110$), 1.805(88)(3 \quad 9 \quad 0), 5.178(45)\left(\begin{array}{lll}1 & 3 & 1\end{array}\right), 4.250(42)(2 \quad 2 \quad 1), 2.926(42)(3 \quad 3 \quad 0)$, 2.684(32)(2 6 1). The empirical formula (based on 28 anions pfu) is $\left(\mathrm{NH}_{4}\right)_{5.77} \mathrm{~K}_{1.42} \mathrm{~Pb}_{0.62} \mathrm{Na}_{1.24} \mathrm{Fe}_{3.96} \mathrm{Mn}_{0.08} \mathrm{~S}_{5.04} \mathrm{O}_{20.16} \mathrm{Cl}_{7.97} \mathrm{Br}_{0.08}$. The idealized formula is $\left(\mathrm{NH}_{4}, \mathrm{~K}, \mathrm{~Pb}^{2+}\right.$, $\mathrm{Na})_{9} \mathrm{Fe}_{4}{ }^{2+}\left(\mathrm{SO}_{4}\right)_{5} \mathrm{Cl}_{8}$. The calculated density is $2.551 \mathrm{~g} \mathrm{~cm}^{-3}$. Using single-crystal diffraction data, the structure was refined to a final $R(F)=0.0363$ for 4614 independent observed reflections $[I>2 \sigma(I)]$. The structure contains two independent, distorted octahedral iron sites, Fe1 and Fe2, with the iron

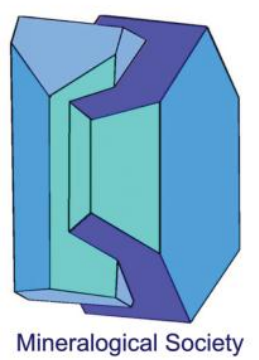

This is a 'preproof' accepted article for Mineralogical Magazine. This version may be subject to change during the production process. DOI: 10.1180/mgm.2018.115. 
atoms in the $2+$ oxidation state, as confirmed by the interatomic distances and bond valence calculations (2.06 and $1.94 v u$, respectively). Fe1 is surrounded by two chlorine atoms and four oxygens of the sulfate ions, with the following average distances $(\AA)$ : $\mathrm{Fe} 1-\mathrm{O} 2.125, \mathrm{Fe} 1-\mathrm{Cl} 2.472$; $\mathrm{Fe} 2$ is surrounded by three chlorine atoms and three oxygens of the sulfate ions, with the following average distances $(\AA)$ : Fe2-O 2.110, Fe2-Cl 2.531. Three independent sulfate anions are also present and are connected with the iron polyhedra to form a tridimensional structure containing voids occupied by four independent ammonium ions (two of them partially replaced by $\mathrm{K}^{+}$), one $\mathrm{Na}^{+} / \mathrm{Pb}^{2+}$ site and one $\mathrm{Cl}^{-}$ion.

Keywords: acmonidesite, new mineral species, volcanic sublimate, crystal structure, Vulcano island, Italy.

\section{INTRODUCTION}

Ammonium sulfate chlorides are quite rare (see for instance rruff.info/ima/), the only examples known to date seem to have been found as sublimates only at Vulcano Island, Aeolian Islands, Sicily, Italy (Campostrini et al., 2011), i.e. adranosite (Demartin et al., 2010), adranosite(Fe) (Mitolo et al., 2013) and therasiaite (Demartin et al., 2014). Acmonidesite $\left(\mathrm{NH}_{4}, \mathrm{~K}, \mathrm{~Pb}^{2+}\right.$, $\mathrm{Na})_{9} \mathrm{Fe}_{4}{ }^{2+}\left(\mathrm{SO}_{4}\right)_{5} \mathrm{Cl}_{8}$, is an additional new mineral of this kind recently found in the fumaroles at the same locality. This mineral was approved as a new species by the IMA Commission on New Minerals, Nomenclature and Classification (No. 2013-068). The name is from Acmonides (from the

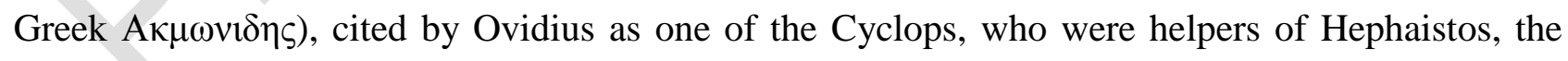
mythological god of fire whose forge was alleged to be located at Vulcano.

This paper deals with the description of the new mineral, together with its crystal structure determination.

Occurrence, Chemical Data and Physical Properties 
Acmonidesite is a volcanic sublimate found at La Fossa crater, Vulcano, Aeolian Islands, Sicily, Italy, in an active fumarole [fumarole FA, reported in Borodaev et al. (2000) and Pinto et al. (2006)] that occurs on a pyroclastic breccia as brown prismatic crystals up to $0.10 \mathrm{~mm}$ in length, in association with salammoniac $\mathrm{NH}_{4} \mathrm{Cl}$, alunite $\mathrm{KAl}_{3}\left(\mathrm{SO}_{4}\right)_{2}(\mathrm{OH})_{6}$ and adranosite $\left(\mathrm{NH}_{4}\right)_{4} \mathrm{NaAl}_{2}\left(\mathrm{SO}_{4}\right) \mathrm{Cl}(\mathrm{OH})_{2}$, (Figure 1). The most commonly observed forms are: $\left\{\begin{array}{lll}1 & 0 & 0\end{array}\right\},\left\{\begin{array}{lll}1 & 2 & 0\end{array}\right\}$, $\left\{\begin{array}{lll}0 & 1 & 1\end{array}\right\},\left\{\begin{array}{lll}0 & 1 & 0\end{array}\right\}$ and $\left\{\begin{array}{lll}1 & 0 & 2\end{array}\right\}$; such an indexing has been obtained by comparison of computergenerated drawings of the crystals. No twinning is apparent. The $a: b: c$ ratio calculated from the unit-cell parameters is 0.5060:1:0.9177 (single-crystal data). The streak is light brown and the lustre is vitreous. Cleavage and fracture were not observed. No fluorescence was observed both under SW and LW ultraviolet radiation. A measurement of the density, obtained by flotation in a diiodomethane-benzene solution, gives the value of $2.56(1) \mathrm{g} \mathrm{cm}^{-3}$. The density calculated using the empirical formula and single-crystal unit-cell data is $2.551 \mathrm{~g} \mathrm{~cm}^{-3}$.

Acmonidesite is biaxial (+) with $\alpha=1.580(2), \beta=1.590(2) \gamma=1.635(2)$ (white light), measured with a spindle stage. $2 \mathrm{~V}($ meas $)=53(3)^{\circ}, 2 \mathrm{~V}($ calc $)=51.6^{\circ}$. Orientation $X=c, Y=b, Z=a$. Taking into account the empirical chemical formula and the density based on it, the calculated mean refractive index is 1.602, using the Gladstone-Dale constants of Mandarino (1976, 1981). The compatibility index $1-\left(\mathrm{K}_{\mathrm{p}} / \mathrm{K}_{\mathrm{c}}\right)=0.033$ is rated as excellent. Dispersion could not be observed because of the intense brown color of the mineral.

Quantitative chemical analyses (8) were carried out in EDS mode using a JEOL JSM 5500 LV scanning electron microscope equipped with an IXRF EDS 2000 microprobe $(20 \mathrm{kV}$ excitation voltage, $10 \mathrm{pA}$ beam current, $2 \mu \mathrm{m}$ beam diameter). The analytical method was chosen because it was impossible to prepare a flat polished sample and the crystal is severely damaged by using the WDS technique, even with a low voltage and current and a large diameter beam. Element concentrations were measured using the $K \alpha$ lines for $\mathrm{S}, \mathrm{K}, \mathrm{Na}, \mathrm{Fe}, \mathrm{Mn}$, and $\mathrm{Cl}$, the $L \alpha$ line for $\mathrm{Br}$ and the $M \alpha$ line for $\mathrm{Pb}$. The presence of ammonium was established from crystal structure analysis, confirmed by the FT infrared spectrum (Figure 2) as well as by the EDS spectrum (Figure 3). The 
IR spectrum was recorded on a Jasco IRT-3000 spectrometer and shows strong absorption bands related to the presence of ammonium at 3214 (broad), 2921, 2851 and $1395 \mathrm{~cm}^{-1}$, together with typical sulfate absorptions at 740,1005, 1083, 1137 and $1218 \mathrm{~cm}^{-1}$. Minor absorptions at 1620 and $1730 \mathrm{~cm}^{-1}$ may be due to partial replacement of $\mathrm{Cl}^{-}$by $\mathrm{OH}^{-}$. The $\left(\mathrm{NH}_{4}\right)_{2} \mathrm{O}$ content was deduced from structure solution, taking into account its partial replacement by $\mathrm{K}^{+}$(see later). The mean analytical results are reported in Table 1. The empirical formula (based on 28 anions pfu) is $\left(\mathrm{NH}_{4}\right)_{5.77} \mathrm{~K}_{1.42} \mathrm{~Pb}_{0.62} \mathrm{Na}_{1.24} \mathrm{Fe}_{3.96} \mathrm{Mn}_{0.08} \mathrm{~S}_{5.04} \mathrm{O}_{20.16} \mathrm{Cl}_{7.97} \mathrm{Br}_{0.08}$. The simplified formula is $\left(\mathrm{NH}_{4}, \mathrm{~K}\right.$, $\left.\mathrm{Pb}^{2+}, \mathrm{Na}\right)_{9} \mathrm{Fe}_{4}{ }^{2+}\left(\mathrm{SO}_{4}\right)_{5} \mathrm{Cl}_{8}$. Holotype material is deposited in the Reference Collection of the Dipartimento di Chimica, Università degli Studi di Milano, specimen number 2013-02.

\section{X-RAY DATA}

X-ray powder-diffraction data (Table 2) have been obtained using a Rigaku DMAX II diffractometer, with graphite monochromatized $\mathrm{CuK \alpha}$ radiation. The indexing of the powderdiffraction pattern was made by comparison with the pattern calculated after the structure determination. The following unit-cell parameters $a=9.840(1), b=19.455(2), c=17.847(2) \AA$, V= 3416.6(5) $\AA^{3}$ were derived from least-squares refinement from the above data using the program UNITCELL (Holland and Redfern, 1997).

Single-crystal diffraction data were collected using a Bruker Apex II diffractometer with Mo $K \alpha$ radiation $\left(\lambda=0.71073 \AA\right.$ ). Some 17663 intensities were measured up to $2 \theta=63.03^{\circ}$, of which 5336 were unique $\left(R_{\text {int }} 0.0501\right)$. A SADABS absorption correction was applied (Sheldrick, 2000) $\left(\mu=5.95 \mathrm{~mm}^{-1}\right)$. On the basis of systematic absences the space group $C 222_{1}$ (no. 20) was unambigously selected, in agreement also with statistical tests on the distribution of the $E$ values $\left[\left|E^{2}-1\right|=0.781\right]$ and confirmed by satisfactory structure solution and refinement. The structure was solved by direct methods and refined using the SHELXL-2017 program (Sheldrick, 2008) implemented in the WinGX suite (Farrugia, 1999) to a final $R=0.0363$ for 4614 observed reflections $[I>2 \sigma(I)]$. A refinement of the occupancies of the $\mathrm{N}$ and $\mathrm{Na}$ sites revealed in two of them a significant substitution of the ammonium ions by $\mathrm{K}^{+}$and of $\mathrm{Na}^{+}$by $\mathrm{Pb}^{2+}$, as shown in Table 4, whereas no occupancy was refined for the $\mathrm{Fe}$ and $\mathrm{Cl}$ sites, due to only small amounts of $\mathrm{Mn}$ and $\mathrm{Br}$ replacing $\mathrm{Fe}$ and $\mathrm{Cl}$, respectively. The formula resulting from the structure refinement is 
$\left(\mathrm{NH}_{4}\right)_{5.77} \mathrm{~K}_{1.22} \mathrm{~Pb}_{0.64} \mathrm{Na}_{1.36} \mathrm{Fe}_{4}\left(\mathrm{SO}_{4}\right)_{5} \mathrm{Cl}_{8}$ (corresponding to 17.63 positive charges for the cations and 18 negative charges for the anions). It seems satisfactory in view of the approximations introduced for the atomic scattering factors of mixed sites. The positions of all the hydrogen atoms of the ammonium ion could not be detected from a difference Fourier map due to local disorder. The value of the Flack parameter, $0.228(8)$, confirms the correctness of the absolute structure, in view with the fact that the crystal is partially twinned and a TWIN refinement was carried out (twin matrix -100 , $0-10,00-1$ and components ratio 0.772(8)/0.228(8)). The coordinates and displacement parameters of the atoms are reported in Table 4; selected interatomic distances are listed in Table 5. The crystallographic files have been deposited with the Principal Editor of Mineralogical Magazine and are available as Supplementary material (see below).

\section{DESCRIPTION OF THE STRUCTURE AND DISCUSSION}

The structure of acmonidesite (Figure 4) contains two independent, distorted octahedral iron sites, $\mathrm{Fe} 1$ and $\mathrm{Fe} 2$, with the iron atoms in the 2+ oxidation state, as confirmed by the range of interatomic distances and bond valence calculations (2.06 and 1.94 vu, respectively). Fe1 is surrounded by two chlorine atoms and four oxygens of the sulfate ions, with the following average distances: Fe1-O $2.125 \AA$, Fe1-Cl $2.472 \AA$; $\mathrm{Fe} 2$ is surrounded by three chlorine atoms and three oxygens of the sulfate ions, with the following average distances: Fe2-O 2.111 $\AA$, Fe2-Cl 2.531. . The structural type of acmonidesite is unprecedented and displays finite clusters made by four iron vertex-sharing distorted octahedra and sulfate tetrahedra (Figure 5), interacting each other only through the sulfate anions. Fe octahedra linked via vertices to form infinite chains ancased from both sides by $\mathrm{SO}_{4}$ tetrahedra are also present in parabutlerite (Plášil et al. 2017), however in acmonidesite each couple of adjacent octahedral is bridged by two sulfate anions instead of by one. The three independent sulfate anions, one of which located on a two-fold axis (S3), are connected to the iron polyhedra and to the other cations as shown in Figure 6. The S1 sulfate shares two vertices of the tetrahedron with two symmetry-related Fe1 polyhedra of the same cluster. The S2 sulfate shares two vertices with $\mathrm{Fe} 1$ and $\mathrm{Fe} 2$ polyhedra of the same cluster and one with a Fe2 of an adjacent cluster. The S3 one shares two of the four vertices with Fe1and Fe2 octahedra of the same cluster and the other two 
with the corresponding $\mathrm{Fe} 1$ and $\mathrm{Fe} 2$ polyhedra related by two-fold symmetry. Voids within the three-dimensional framework determined by the arrangement of these clusters are occupied by four independent ammonium ions (two of them partially replaced by $\mathrm{K}^{+}$), by one $\mathrm{Na}^{+}$cation, partially substituted by $\mathrm{Pb}^{2+}$ and one $\mathrm{Cl}^{-}$anion (Cl5). The larger voids are those occupied by ammonium only (average radius of the cage 3.32-3.46 $\AA$ ) or by ammonium plus potassium (average radius 3.12-3.14 $\AA$ ). The smallest (average radius $2.79 \AA$ ) are occupied by $\mathrm{Na}^{+}$and $\mathrm{Pb}^{2+}$, as expected by the ionic radii of these cations. Bond valence calculations (Table 5) are in agreement with the structure model proposed. The value of $1.421 \mathrm{vu}$ obtained for the $\mathrm{Na} / \mathrm{Pb}$ site accounts for the presence of an amount of the divalent $\mathrm{Pb}^{2+}$ cation.

The ammonium ions interact with the surrounding sulfate oxygens and chloride ions via hydrogen bonds. The three sulfate anions display S-O distances ranging from 1.448(5) to 1.483(4) $\AA$ with an overall average distance of $1.465 \AA$, not significantly different from the grand mean S-O distance reported by Hawthorne et al. (2000).

In spite of the similar chemical composition with adranosite-(Fe) and therasiaite, no topological relationship of acmonidesite with them is evident. In adranosite-(Fe) iron is present only in the $3+$ oxidation state, and its polyhedron does not contain chlorine which is instead coordinated to Na; the $\mathrm{FeO}_{4}(\mathrm{OH})_{2}$ distorted octahedra and sulfate tetrahedra are linked to form helicoidal chains extending along [001]. Two different oxidation states for iron are instead present in therasiaite, where three chlorides and three oxygens of the sulfate anions are octahedrally coordinated to the metal centre thus forming $\left[\mathrm{Fe}_{2}\left(\mathrm{SO}_{4}\right)_{3} \mathrm{Cl}_{5}{ }^{6-}\right]_{\mathrm{n}}$ infinite chains along [001].

The occurrence of acmonidesite in the fumaroles at La Fossa Crater, together with other rare and unique minerals containing ammonium, is an additional example of the singularity of this locality and provides further information in the study of the overall geochemical context of this environment. The presence of this minerals as volcanic sublimates emphasizes an high activity of free ammonia and volatile chlorides in the gas phase that prevent dissociation of such minerals, which would be otherwise unstable at the observed temperature. 


\section{ACKNOWLEDGEMENTS}

The authors are most indebted to Prof. Silvia Bruni for the FTIR measurements and to the referees Sergey Krivovichev, Peter Leverett and an anonymous referee for useful suggestions.

\section{Supplementary material}

To view supplementary material for this article, please visit https://doi.org/

\section{REFERENCES}

Borodaev, Y.S., Garavelli, A., Garbarini, C., Grillo, S.M., Mozgova, N.N., Organova, N.I., Trubkin, N.V. and Vurro, F. (2000) Rare sulfosalts from Vulcano, Aeolian Islands, Italy. III. Wittite and cannizzarite. The Canadian Mineralogist, 38, 23-34.

Brown, I.D. (2009) Recent developments in the methods and applications of the bond valence model. Chemical Reviews, 109, 6858-6919.

Brown, I.D. and Altermatt, D. (1985) Bond-valence parameters from a systematic analysis of the inorganic crystal structure database. Acta Crystallographica, B41, 244-247.

Bruker (2001) SMART and SAINT. Bruker AXS Inc., Madison, Wisconsin, USA.

Campostrini, I., Demartin, F., Gramaccioli, C.M. and Russo, M. (2011) Vulcano. Tre secoli di mineralogia. Associazione Micro-mineralogica Italiana Ed., Cremona - Italy, 344 pages, ISBN 978-88-905541-0-0.

Demartin, F., Gramaccioli, C.M. and Campostrini, I. (2010) Adranosite, $\left(\mathrm{NH}_{4}\right)_{4} \mathrm{NaAl}_{2}\left(\mathrm{SO}_{4}\right)_{4} \mathrm{Cl}(\mathrm{OH})_{2}$, a new ammonium sulfate chloride from La Fossa Crater, Vulcano, Aeolian Islands, Italy. The Canadian Mineralogist, 48, 315-321.

Demartin, F., Castellano, C. and Campostrini, I. (2014) Therasiaite, $\left(\mathrm{NH}_{4}\right)_{3} \mathrm{KNa}_{2} \mathrm{Fe}^{2+} \mathrm{Fe}^{3+}\left(\mathrm{SO}_{4}\right)_{3} \mathrm{Cl}_{5}$, a new sulfate chloride from La Fossa Crater, Vulcano, Aeolian Islands, Italy. Mineralogical Magazine, 78, 203-213. 
Farrugia, L.J. (1999) WinGX suite for small-molecule single-crystal crystallography. Journal of Applied Crystallography, 32, 837-838.

Fischer, R.X. and Tillmanns, E. (1988) The equivalent isotropic displacement factor. Acta Crystallographica, C44, 775-776

Hawthorne, F.C., Krivovichev, S.V. and Burns, P.C. (2000) The crystal chemistry of sulfate minerals. In C.N. Alpers, J.L. Jambor, and B.K. Nordstrom, Eds., Sulfate MineralsCrystallography, Geochemistry, and Environmental Significance, 40, p. 1-112. Reviews in Mineralogy and Geochemistry, Mineralogical Society of America, Chantilly, Virginia.

Holland, T.J.B. and Redfern, S.A.T. (1997) Unit cell refinement from powder diffraction data: the use of regression diagnostics. Mineralogical Magazine, 61, 65-77.

Mandarino, J. A. (1976) The Gladstone-Dale relationship I. Derivation of new constants. The Canadian Mineralogist, 14, 498-502.

Mandarino, J.A. (1981) The Gladstone-Dale relationship. IV. The compatibility index and its application. The Canadian Mineralogist, 19, 441-450.

Mitolo, D., Demartin, F., Garavelli, A., Campostrini, I., Pinto, D., Gramaccioli, C.M., Acquafredda, P. and Kolitsch, U. (2013) Adranosite-(Fe), $\left(\mathrm{NH}_{4}\right)_{4} \mathrm{NaFe}_{2}\left(\mathrm{SO}_{4}\right)_{4} \mathrm{Cl}(\mathrm{OH})_{2}$, a new ammonium chloride from La Fossa Crater, Vulcano, Aeolian Islands, Italy. The Canadian Mineralogist, 51, $57-66$.

Pinto, D., Balić Žunić, T., Garavelli, A., Garbarino, C., Makovický, E. and Vurro, F. (2006) First occurrence of close-to-ideal kirkiite at Vulcano (Aeolian Islands, Italy): chemical data and single crystal X-ray study. European Journal of Mineralogy, 18, 393-401.

Plášil J. Petřiček V and Majzlan J. (2017) A commensurately modulated structure of parabutlerite, $\mathrm{Fe}^{\mathrm{III}} \mathrm{SO}_{4}(\mathrm{OH}) \cdot 2 \mathrm{H}_{2} \mathrm{O}$. Acta Crystallographica, B73, 856-862.

Sheldrick, G.M. (2000) SADABS Area-Detector Absorption Correction Program, Bruker AXS Inc., Madison, WI, USA.

Sheldrick, G.M. (2008) A short history of SHELX. Acta Crystallographica, A64, 112-122. 
Demartin et al.

Table 1. Analytical data for acmonidesite (average of 8 analyses).

\begin{tabular}{|c|c|c|c|c|}
\hline Constituent & wt\% & Range & SD & Probe Standard \\
\hline$\left(\mathrm{NH}_{4}\right)_{2} \mathrm{O} *$ & 11.05 & & & $\mathrm{KBr}$ \\
\hline $\mathrm{K}_{2} \mathrm{O}$ & 4.91 & $4.28-6.14$ & 0.27 & Natural albite \\
\hline $\mathrm{Na}_{2} \mathrm{O}$ & 2.82 & $2.28-3.54$ & 0.22 & $\begin{array}{c}\text { Natural almandine } \\
\text { garnet }\end{array}$ \\
\hline $\mathrm{FeO}$ & 20.93 & $19.51-21.88$ & 0.25 & $\begin{array}{c}\text { Natural almandine } \\
\text { garnet }\end{array}$ \\
\hline $\mathrm{MnO}$ & 0.42 & $0.15-1.24$ & 0.10 & phosgenite \\
\hline $\mathrm{PbO}$ & 10.25 & $7.03-12.23$ & 0.99 & Synthetic anhydrite \\
\hline $\mathrm{SO}$ & 29.67 & $27.46-32.51$ & 0.37 & phosgenite \\
\hline $\mathrm{Cl}$ & 20.80 & $18.42-23.46$ & 0.50 & $\mathrm{KBr}$ \\
\hline $\mathrm{Br}$ & 0.45 & $0.36-0.51$ & 0.20 & \\
\hline $\mathrm{O}=\mathrm{Cl}$ & -4.75 & & & \\
\hline $\mathrm{Total}$ & 96.55 & & & \\
\hline
\end{tabular}

* From structure solution

The empirical formula (based on 28 anions $p f u$ ) is $\left(\mathrm{NH}_{4}\right)_{5.77} \mathrm{~K}_{1.42} \mathrm{~Pb}_{0.62} \mathrm{Na}_{1.24} \mathrm{Fe}_{3.96} \mathrm{Mn}_{0.08} \mathrm{~S}_{5.04}$

$\mathrm{O}_{20.16} \mathrm{Cl}_{7.97} \mathrm{Br}_{0.08}$. The simplified formula is $\left(\mathrm{NH}_{4}, \mathrm{~K}, \mathrm{~Pb}^{2+}, \mathrm{Na}\right)_{9} \mathrm{Fe}_{4}{ }^{2+}\left(\mathrm{SO}_{4}\right)_{5} \mathrm{Cl}_{8}$. 
Table 2. X-ray powder diffraction data for acmonidesite.

\begin{tabular}{|c|c|c|c|}
\hline$h k l$ & $I_{\mathrm{rel}}$ & $d_{\text {obs }}(\AA)$ & $d_{\text {calc }}(\AA)^{*}$ \\
\hline 020 & 12 & 9.704 & 9.727 \\
\hline 002 & 37 & 9.049 & 8.924 \\
\hline 110 & 100 & 8.766 & 8.781 \\
\hline 021 & 1 & 8.544 & 8.541 \\
\hline 111 & 14 & 7.860 & 7.879 \\
\hline 022 & 22 & 6.570 & 6.576 \\
\hline 131 & 45 & 5.178 & 5.182 \\
\hline 040 & 9 & 4.850 & 4.864 \\
\hline 221 & 42 & 4.250 & 4.263 \\
\hline 024 & 13 & 4.044 & 4.056 \\
\hline 043 & 1 & 3.776 & 3.765 \\
\hline 150 & 25 & 3.605 & 3.618 \\
\hline 134 & 14 & 3.449 & 3.443 \\
\hline 241 & 8 & 3.407 & 3.396 \\
\hline 025 & 26 & 3.346 & 3.351 \\
\hline 044 & 9 & 3.275 & 3.288 \\
\hline 310 & 23 & 3.230 & 3.234 \\
\hline 061 & 29 & 3.203 & 3.190 \\
\hline 153 & 21 & 3.085 & 3.091 \\
\hline 135 & 18 & 2.983 & 2.980 \\
\hline 006 & 24 & 2.969 & 2.975 \\
\hline 330 & 42 & 2.926 & 2.927 \\
\hline 313 & 10 & 2.833 & 2.842 \\
\hline 154 & 13 & 2.804 & 2.810 \\
\hline 261 & 32 & 2.684 & 2.677 \\
\hline 334 & M & 2.444 & 2.447 \\
\hline 422 & $\bar{P}$ & 2.304 & 2.304 \\
\hline 207 & 27 & 2.266 & 2.264 \\
\hline 028 & 9 & 2.175 & 2.174 \\
\hline 084 & 2 & 2.136 & 2.135 \\
\hline 405 & 3 & 2.023 & 2.026 \\
\hline 228 & 2 & 1.992 & 1.989 \\
\hline 267 & 13 & 1.858 & 1.856 \\
\hline 195 & 10 & 1.814 & 1.817 \\
\hline 390 & 88 & 1.805 & 1.805 \\
\hline 391 & 24 & 1.797 & 1.796 \\
\hline 446 & 2 & 1.768 & 1.766 \\
\hline 553 & 4 & 1.683 & 1.684 \\
\hline 483 & 9 & 1.662 & 1.661 \\
\hline 602 & 2 & 1.615 & 1.613 \\
\hline
\end{tabular}

*Calculated from the unit cell $a=9.840(1), b=19.455(2), c=17.847(2) \AA, V=3416.6(5) \AA^{3}$, obtained from least-squares refinement of the above data using the program UNITCELL (Holland and Redfern, 1997). 


\section{Demartin et al.}

Table 3. Single-crystal diffraction data and refinement parameters for acmonidesite

\begin{tabular}{|c|c|}
\hline Crystal system & orthorhombic \\
\hline Space Group & $C 222_{1}$ (no. 20) \\
\hline$a(\AA)$ & $9.841(1))$ \\
\hline$b(\AA)$ & $19.448(3)$ \\
\hline$c(\AA)$ & $17.847(3)$ \\
\hline$V\left(\AA^{3}\right)$ & $3415.7(9)$ \\
\hline$Z$ & 4 \\
\hline Radiation & $\operatorname{MoK\alpha }$ \\
\hline$\mu\left(\mathrm{mm}^{-1}\right)$ & 5.95 \\
\hline$D_{\text {calc }}\left(\mathrm{g} \mathrm{cm}^{-3}\right)$ & 2.551 \\
\hline Measured reflections & 17663 \\
\hline$R_{\text {int }}$ & 0.0501 \\
\hline Independent reflections & 5336 \\
\hline Observed reflections $[I>2 \sigma(I)]$ & 4614 \\
\hline Parameters refined & 214 \\
\hline Final $R[I>2 \sigma(I)]$ and $w R 2$ (all data) & $0.0363,0.0945$ \\
\hline$S$ & 1.037 \\
\hline
\end{tabular}

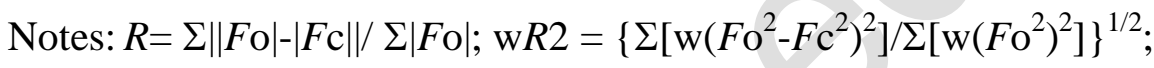

$\mathrm{w}=1 /\left[\sigma^{2}\left(F_{\mathrm{O}}^{2}\right)+(0.0563 \mathrm{q})^{2}\right]$ where $\mathrm{q}=\left[\max \left(0, F_{\mathrm{o}}{ }^{2}\right)+2 F \mathrm{c}^{2}\right] / 3$

$S=\left\{\Sigma\left[\mathrm{w}\left(F_{\mathrm{o}^{2}}-F \mathrm{c}^{2}\right)\right] /(\mathrm{n}-\mathrm{p})\right\}^{1 / 2}$ where $\mathrm{n}$ is the number of reflections and $\mathrm{p}$ is the number of refined parameters. 
Demartin et al.

Table 4. Final atom coordinates and equivalent isotropic displacement parameters $\left(\AA^{2}\right)$.

\begin{tabular}{lcccccc}
\hline Atom & $\begin{array}{c}\text { Wyckoff } \\
\text { site }\end{array}$ & occupancy & $x / a$ & $y / b$ & $z / c$ & Ueq \\
& & & & & \\
$\mathrm{Fe} 1$ & $8 c$ & 1 & $0.06089(8)$ & $0.09769(4)$ & $0.14882(4)$ & $0.01876(18)$ \\
$\mathrm{Fe} 2$ & $8 c$ & 1 & $0.32631(7)$ & $0.15792(4)$ & $-0.00614(5)$ & $0.01962(17)$ \\
$\mathrm{S} 1$ & $8 c$ & 1 & $0.19697(12)$ & $0.00302(8)$ & $0.28715(7)$ & $0.0218(3)$ \\
$\mathrm{S} 2$ & $8 c$ & 1 & $-0.01601(12)$ & $0.18634(6)$ & $-0.00283(7)$ & $0.0165(2)$ \\
$\mathrm{S} 3$ & $4 a$ & 1 & $0.16498(15)$ & 0 & 0 & $0.0138(3)$ \\
$\mathrm{O} 1$ & $8 c$ & 1 & $0.3439(5)$ & $0.0072(4)$ & $0.2850(3)$ & $0.0652(19)$ \\
$\mathrm{O} 2$ & $8 c$ & 1 & $0.1430(5)$ & $0.0169(2)$ & $0.2111(2)$ & $0.0314(10)$ \\
$\mathrm{O} 3$ & $8 c$ & 1 & $0.1508(6)$ & $-0.0668(3)$ & $0.3071(3)$ & $0.0521(15)$ \\
$\mathrm{O} 4$ & $8 c$ & 1 & $0.1425(4)$ & $0.0534(2)$ & $0.3402(2)$ & $0.0309(9)$ \\
$\mathrm{O} 5$ & $8 c$ & 1 & $0.1255(4)$ & $0.2045(3)$ & $-0.0185(3)$ & $0.0431(13)$ \\
$\mathrm{O} 6$ & $8 c$ & 1 & $-0.1040(5)$ & $0.2458(2)$ & $-0.0174(3)$ & $0.0373(11)$ \\
$\mathrm{O} 7$ & $8 c$ & 1 & $-0.0601(7)$ & $0.1307(3)$ & $-0.0515(3)$ & $0.0499(14)$ \\
$\mathrm{O} 8$ & $8 c$ & 1 & $-0.0306(5)$ & $0.1659(3)$ & $0.0756(3)$ & $0.0403(12)$ \\
$\mathrm{O} 9$ & $8 c$ & 1 & $0.2498(5)$ & $0.0580(2)$ & $-0.0234(3)$ & $0.0445(14)$ \\
$\mathrm{O} 10$ & $8 c$ & 1 & $0.0781(4)$ & $0.0199(2)$ & $0.0631(2)$ & $0.0266(8)$ \\
$\mathrm{C} 11$ & $8 c$ & 1 & $0.29077(14)$ & $0.14689(7)$ & $0.13413(8)$ & $0.0259(3)$ \\
$\mathrm{Cl} 2$ & $4 b$ & 1 & 0 & $0.17900(10)$ & 0.25 & $0.0295(4)$ \\
$\mathrm{Cl3}$ & $8 c$ & 1 & $0.3433(2)$ & $0.16197(9)$ & $-0.14856(9)$ & $0.0400(4)$ \\
$\mathrm{C} 14$ & $8 c$ & 1 & $0.55827(13)$ & $0.10510(7)$ & $0.00109(9)$ & $0.0299(3)$ \\
$\mathrm{Cl5}$ & $4 b$ & 1 & 0 & $-0.21271(12)$ & 0.25 & $0.0408(5)$ \\
$\mathrm{Na} / \mathrm{Pb}$ & $8 c$ & $0.68(1) / 0.32(1)$ & $0.07476(6)$ & $-0.10348(3)$ & $0.15782(3)$ & $0.0251(2)$ \\
$\mathrm{N} 1 / \mathrm{K} 1$ & $4 a$ & $0.74(1) / 0.26(1)$ & $-0.1854(4)$ & 0 & 0 & $0.0304(14)$ \\
$\mathrm{N} 2 / \mathrm{K} 2$ & $8 c$ & $0.52(1) / 0.48(1)$ & $0.43348(19)$ & $0.00093(12)$ & $-0.13237(11)$ & $0.0288(7)$ \\
$\mathrm{N} 3$ & $8 c$ & 1 & $0.1904(6)$ & $0.3092(3)$ & $0.1455(3)$ & $0.0367(13)$ \\
$\mathrm{N} 4$ & $8 c$ & 1 & $-0.3063(6)$ & $0.1870(3)$ & $0.1444(3)$ & $0.0348(12)$ \\
\hline & & & & &
\end{tabular}

\begin{tabular}{lcccccc}
\hline \multicolumn{1}{c}{ Atom } & $\boldsymbol{U}_{\mathbf{1 1}}$ & $\boldsymbol{U}_{\mathbf{2 2}}$ & $\boldsymbol{U}_{\mathbf{3 3}}$ & $\boldsymbol{U}_{\mathbf{2 3}}$ & $\boldsymbol{U}_{\mathbf{1 3}}$ & $\boldsymbol{U}_{\mathbf{1 2}}$ \\
\hline Fe1 & $0.0211(4)$ & $0.0192(4)$ & $0.0159(3)$ & $0.0004(3)$ & $0.0005(3)$ & $0.0014(3)$ \\
Fe2 & $0.0188(3)$ & $0.0135(3)$ & $0.0265(4)$ & $0.0005(3)$ & $0.0002(3)$ & $-0.0024(2)$ \\
S1 & $0.0175(5)$ & $0.0299(7)$ & $0.0180(5)$ & $0.0047(6)$ & $0.0000(4)$ & $0.0030(6)$ \\
S2 & $0.0197(5)$ & $0.0120(5)$ & $0.0179(5)$ & $0.0015(5)$ & $-0.0001(5)$ & $0.0030(4)$ \\
S3 & $0.0144(6)$ & $0.0115(6)$ & $0.0154(6)$ & $-0.0010(7)$ & 0 & 0 \\
O1 & $0.019(2)$ & $0.135(6)$ & $0.041(3)$ & $-0.015(4)$ & $-0.005(2)$ & $0.002(4)$ \\
O2 & $0.043(2)$ & $0.032(2)$ & $0.0191(18)$ & $-0.0001(16)$ & $-0.0069(17)$ & $0.0071(19)$ \\
O3 & $0.058(3)$ & $0.028(3)$ & $0.070(4)$ & $0.016(3)$ & $0.022(3)$ & $0.007(2)$ \\
O4 & $0.027(2)$ & $0.040(3)$ & $0.025(2)$ & $-0.0069(18)$ & $-0.0004(17)$ & $0.0030(19)$ \\
O5 & $0.022(2)$ & $0.041(3)$ & $0.065(4)$ & $0.027(2)$ & $0.009(2)$ & $0.0043(19)$ \\
O6 & $0.036(2)$ & $0.020(2)$ & $0.057(3)$ & $0.0018(19)$ & $-0.007(2)$ & $0.0120(18)$ \\
O7 & $0.078(4)$ & $0.025(2)$ & $0.047(3)$ & $-0.013(2)$ & $-0.021(3)$ & $0.003(3)$ \\
O8 & $0.038(2)$ & $0.056(3)$ & $0.027(2)$ & $0.021(2)$ & $0.0080(19)$ & $0.017(2)$ \\
O9 & $0.053(3)$ & $0.026(2)$ & $0.055(3)$ & $-0.015(2)$ & $0.029(2)$ & $-0.025(2)$ \\
O10 & $0.029(2)$ & $0.031(2)$ & $0.0197(17)$ & $-0.0094(15)$ & $0.0048(16)$ & $-0.0067(17)$ \\
C11 & $0.0251(6)$ & $0.0237(6)$ & $0.0289(7)$ & $-0.0002(5)$ & $-0.0012(5)$ & $-0.0023(5)$ \\
C12 & $0.0455(12)$ & $0.0206(9)$ & $0.0225(9)$ & 0 & $0.0078(8)$ & 0 \\
C13 & $0.0568(11)$ & $0.0327(8)$ & $0.0304(8)$ & $0.0040(6)$ & $-0.0020(7)$ & $0.0097(8)$
\end{tabular}




$\begin{array}{lcccccc}\mathrm{Cl} 4 & 0.0226(5) & 0.0294(7) & 0.0375(7) & -0.0006(7) & -0.0006(6) & 0.0043(5) \\ \mathrm{Cl} 5 & 0.0432(13) & 0.0323(12) & 0.0469(13) & 0 & 0.0120(10) & 0 \\ \mathrm{Na} / \mathrm{Pb} & 0.0262(3) & 0.0234(3) & 0.0256(3) & -0.0053(2) & -0.0012(2) & 0.0006(2) \\ \mathrm{N} 1 / \mathrm{K} 1 & 0.0213(19) & 0.033(2) & 0.037(2) & -0.007(2) & 0 & 0 \\ \mathrm{~N} 2 / \mathrm{K} 2 & 0.0265(10) & 0.0298(11) & 0.0302(11) & -0.0014(9) & 0.0049(7) & 0.0018(10) \\ \mathrm{N} 3 & 0.037(3) & 0.027(3) & 0.046(3) & 0.003(2) & -0.005(3) & 0.002(2) \\ \mathrm{N} 4 & 0.039(3) & 0.025(3) & 0.040(3) & -0.006(2) & -0.001(2) & 0.002(2)\end{array}$

The anisotropic displacement factor exponent takes the form:

$-2 \pi^{2}\left(U_{11} h^{2}\left(\mathrm{a}^{*}\right)^{2}+\ldots+2 U_{12} h k \mathrm{a}^{*} \mathrm{~b}^{*}+\ldots\right) ; U_{\text {eq }}$ according to Fischer and Tillmans (1988) 


\section{Demartin et al.}

Table 5. Selected interatomic distances $(\AA)$ and bond valences* (vu) in acmonidesite.

\begin{tabular}{|c|c|c|c|c|c|}
\hline Fe1-O2 & $2.086(4)$ & 0.386 & Fe2-O5 & $2.185(4)$ & 0.296 \\
\hline $\mathrm{Fe} 1-\mathrm{O} 4^{\mathrm{a}}$ & $2.188(4)$ & 0.293 & $\mathrm{Fe} 2-\mathrm{O}^{\mathrm{b}}$ & $2.039(4)$ & 0.438 \\
\hline Fe1-O8 & $2.068(4)$ & 0.405 & Fe2-O9 & $2.107(4)$ & 0.365 \\
\hline Fe1-O10 & $2.158(4)$ & 0.318 & Fe2-Cl1 & $2.537(2)$ & 0.275 \\
\hline Fe1-Cl1 & $2.470(2)$ & 0.330 & $\mathrm{Fe} 2-\mathrm{Cl} 3$ & $2.549(2)$ & 0.267 \\
\hline $\mathrm{Fe} 1-\mathrm{Cl} 2$ & $2.474(2)$ & 0.327 & $\mathrm{Fe} 2-\mathrm{Cl} 4$ & $2.507(1)$ & 0.299 \\
\hline$\langle\mathrm{Fe} 1-\varphi\rangle$ & 2.241 & $\Sigma=2.059$ & $\langle\mathrm{Fe} 2-\varphi\rangle$ & 2.321 & $\Sigma=1.940$ \\
\hline N1/K1-O7 & $2.970(6)$ & 0.122 & $\mathrm{Na} / \mathrm{Pb}-\mathrm{O} 2$ & $2.615(4)$ & 0.160 \\
\hline $\mathrm{N} 1 / \mathrm{K} 1-\mathrm{O} 7^{\mathrm{c}}$ & $2.970(6)$ & 0.122 & $\mathrm{Na} / \mathrm{Pb}-\mathrm{O} 3$ & $2.857(6)$ & 0.091 \\
\hline $\mathrm{N} 1 / \mathrm{K} 1-\mathrm{O} 4^{\mathrm{f}}$ & $3.064(4)$ & 0.095 & $\mathrm{Na} / \mathrm{Pb}-\mathrm{O} 10$ & $2.935(4)$ & 0.076 \\
\hline $\mathrm{N} 1 / \mathrm{K} 1-\mathrm{O} 4^{\mathrm{g}}$ & $3.064(4)$ & 0.095 & $\mathrm{Na} / \mathrm{Pb}-\mathrm{O}^{\mathrm{a}}$ & $2.414(6)$ & 0.258 \\
\hline N1/K1-O10 & $2.853(5)$ & 0.166 & $\mathrm{Na} / \mathrm{Pb}-\mathrm{O}^{\mathrm{c}}$ & $3.207(6)$ & 0.040 \\
\hline $\mathrm{N} 1 / \mathrm{K} 1-\mathrm{O} 10^{\mathrm{c}}$ & $2.853(5)$ & 0.166 & $\mathrm{Na} / \mathrm{Pb}-\mathrm{O} 7^{\mathrm{c}}$ & $2.375(6)$ & 0.282 \\
\hline $\mathrm{N} 1 / \mathrm{K} 1-\mathrm{O} 8^{\mathrm{c}}$ & $3.814(6)$ & 0.013 & $\mathrm{Na} / \mathrm{Pb}-\mathrm{O}^{\mathrm{c}}$ & $3.084(6)$ & 0.053 \\
\hline $\mathrm{N} 1 / \mathrm{K} 1-\mathrm{Cl} 4^{\mathrm{d}}$ & $3.247(3)$ & 0.167 & $\mathrm{Na} / \mathrm{Pb}-\mathrm{Cl}^{\mathrm{c}}$ & $2.882(2)$ & 0.259 \\
\hline $\mathrm{N} 1 / \mathrm{K} 1-\mathrm{Cl} 4^{\mathrm{e}}$ & $3.247(3)$ & 0.167 & $\mathrm{Na} / \mathrm{Pb}-\mathrm{Cl} 5$ & $2.786(2)$ & 0.202 \\
\hline$\langle\mathrm{N} 1 / \mathrm{K} 1-\varphi\rangle$ & 3.120 & $\Sigma=1.113$ & $\langle\mathrm{Na} / \mathrm{Pb}-\varphi\rangle$ & 2.795 & $\Sigma=1.421$ \\
\hline $\mathrm{N} 2 / \mathrm{K} 2-\mathrm{O} 1^{\mathrm{h}}$ & $2.646(5)$ & 0.261 & $\mathrm{~N} 3-\mathrm{O}^{\mathrm{i}}$ & $2.996(8)$ & 0.123 \\
\hline $\mathrm{N} 2 / \mathrm{K} 2-\mathrm{O} 1^{\mathrm{c}}$ & $2.868(5)$ & 0.147 & $\mathrm{~N} 3-\mathrm{O} 5$ & $3.623(8)$ & 0.023 \\
\hline $\mathrm{N} 2 / \mathrm{K} 2-\mathrm{O} 2^{\mathrm{c}}$ & $3.204(5)$ & 0.062 & $\mathrm{~N} 3-06^{\mathrm{b}}$ & $3.235(8)$ & 0.064 \\
\hline N2/K2-O9 & $2.878(5)$ & 0.143 & $\mathrm{~N} 3-\mathrm{O}^{\mathrm{b}}$ & $3.195(8)$ & 0.072 \\
\hline $\mathrm{N} 2 / \mathrm{K} 2-\mathrm{O} 9^{\mathrm{c}}$ & $3.508(6)$ & 0.029 & N3-O8 & $3.749(8)$ & 0.016 \\
\hline $\mathrm{N} 2 / \mathrm{K} 2-\mathrm{Cl} 3$ & $3.268(3)$ & 0.146 & N3-Cl1 & $3.313(6)$ & 0.153 \\
\hline N2/K2-Cl4 & $3.359(3)$ & 0.118 & N3-Cl2 & $3.661(6)$ & 0.060 \\
\hline $\mathrm{N} 2 / \mathrm{K} 2-\mathrm{Cl} 1^{\mathrm{c}}$ & $3.200(3)$ & 0.171 & $\mathrm{~N} 3-\mathrm{Cl}^{\mathrm{m}}$ & $3.733(6)$ & 0.049 \\
\hline $\mathrm{N} 2 / \mathrm{K} 2-\mathrm{Cl} 4^{\mathrm{c}}$ & $3.354(3)$ & 0.119 & $\mathrm{~N} 3-\mathrm{Cl}^{\mathrm{j}}$ & $3.462(6)$ & 0.103 \\
\hline \multirow[t]{2}{*}{$\langle\mathrm{N} 2 / \mathrm{K} 2-\varphi\rangle$} & 3.143 & $\Sigma=1.196$ & $\mathrm{~N} 3-\mathrm{Cl} 4^{\mathrm{j}}$ & $3.363(6)$ & 0.134 \\
\hline & & & $\mathrm{N} 3-\mathrm{Cl}^{\mathrm{n}}$ & $3.598(6)$ & 0.071 \\
\hline $\mathrm{N} 4-\mathrm{O} 1^{\mathrm{a}}$ & $3.736(10)$ & 0.017 & $\mathrm{~N} 3-\mathrm{Cl}^{\mathrm{i}}$ & $3.598(6)$ & 0.071 \\
\hline $\mathrm{N} 4-\mathrm{O} 4^{\mathrm{a}}$ & $3.071(7)$ & 0.100 & $\langle\mathrm{~N} 3-\varphi\rangle$ & 3.460 & $\Sigma=0.939$ \\
\hline $\mathrm{N} 4-\mathrm{O5}^{\mathrm{j}}$ & $3.153(7)$ & 0.080 & & & \\
\hline N4-O6 & $3.688(8)$ & 0.019 & S1-O1 & $1.448(5)$ & 1.609 \\
\hline N4-O8 & $3.006(7)$ & 0.120 & $\mathrm{~S} 1-\mathrm{O} 2$ & $1.483(4)$ & 1.464 \\
\hline $\mathrm{N} 4-\mathrm{Cl}^{\mathrm{j}}$ & $3.286(6)$ & 0.165 & $\mathrm{~S} 1-\mathrm{O} 3$ & $1.475(5)$ & 1.492 \\
\hline $\mathrm{N} 4-\mathrm{Cl}^{\mathrm{d}}$ & $3.294(6)$ & 0.162 & $\mathrm{~S} 1-\mathrm{O} 4$ & $1.464(4)$ & 1.541 \\
\hline $\mathrm{N} 4-\mathrm{Cl}^{\mathrm{k}}$ & $3.315(6)$ & 0.153 & $\langle\mathrm{~S} 1-\mathrm{O}\rangle$ & 1.468 & $\Sigma=6.106$ \\
\hline $\mathrm{N} 4-\mathrm{Cl}^{1}$ & $3.315(6)$ & 0.153 & & & \\
\hline \multirow[t]{2}{*}{$\langle N 4-\varphi\rangle$} & 3.318 & $\Sigma=0.969$ & $\mathrm{~S} 2-\mathrm{O} 5$ & $1.464(4)$ & 1.541 \\
\hline & & & S2-O6 & $1.467(4)$ & 1.529 \\
\hline S3-O9 & $1.463(4)$ & 1.545 & S2-O7 & $1.455(5)$ & 1.579 \\
\hline S3-O10 & $1.466(4)$ & 1.533 & S2-O8 & $1.462(4)$ & 1.549 \\
\hline $\mathrm{S} 3-09^{\mathrm{c}}$ & $1.463(4)$ & 1.545 & $\langle\mathrm{~S} 2-\mathrm{O}\rangle$ & 1.462 & $\Sigma=6.198$ \\
\hline $\mathrm{S} 3-\mathrm{O} 10^{\mathrm{c}}$ & $1.466(4)$ & 1.533 & & & \\
\hline$\langle\mathrm{S} 3-\mathrm{O}\rangle$ & 1.465 & $\Sigma=6.156$ & & & \\
\hline
\end{tabular}


Symmetry codes: $a=-x, y, 1 / 2-z ; b=x+1 / 2,1 / 2-y,-z ; c=x,-y,-z ; d=x-1, y, z ; e=x-1,-$ $y,-z ; f=-x,-y, z-1 / 2 ; g=-x, y, 1 / 2-z ; h=1-x,-y, z-1 / 2 ; i=1 / 2-x, y+1 / 2,1 / 2-z ; j=x-1 / 2,1 / 2-y,-z ;$ $\mathrm{k}=\mathrm{x}-1 / 2, \mathrm{y}+1 / 2, \mathrm{z} ; \mathrm{l}=-\mathrm{x}-1 / 2, \mathrm{y}+1 / 2,1 / 2-\mathrm{z}, \mathrm{m}=1 / 2-\mathrm{x}, 1 / 2-\mathrm{y}, \mathrm{z}+1 / 2, \mathrm{n}=\mathrm{x}+1 / 2, \mathrm{y}+1 / 2, \mathrm{z}$.

* Bond-valence parameters from Brown and Altermatt (1985), and Brown (2009). 


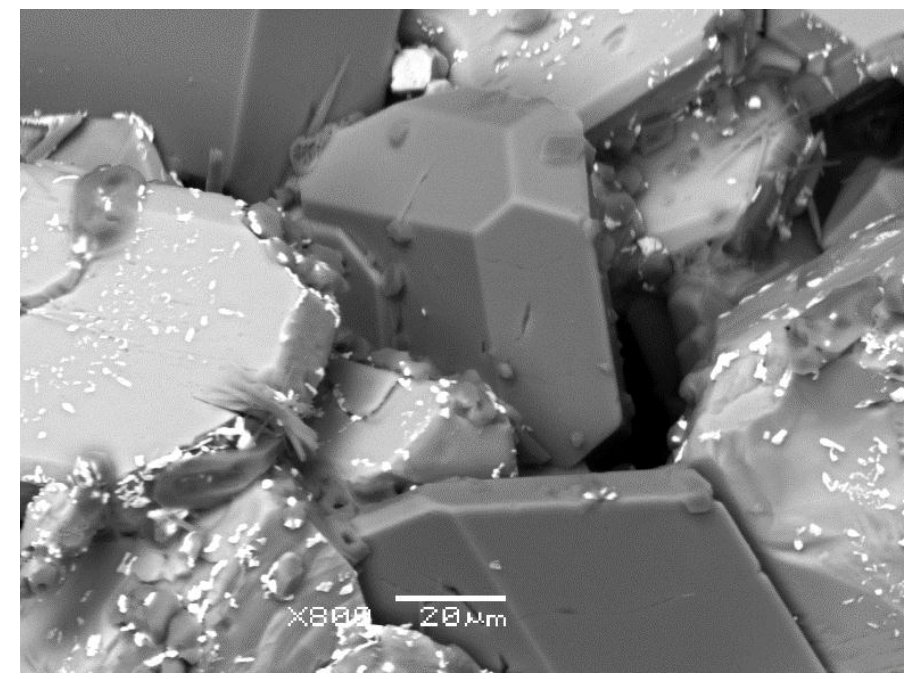

(a)

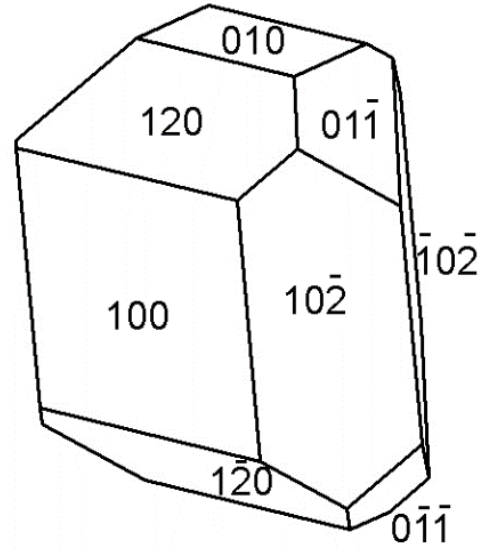

(b)

Figure 1. SEM-BSE image of crystals of acmonidesite with alunite (a) and a crystal drawing with indexing of the faces (b).

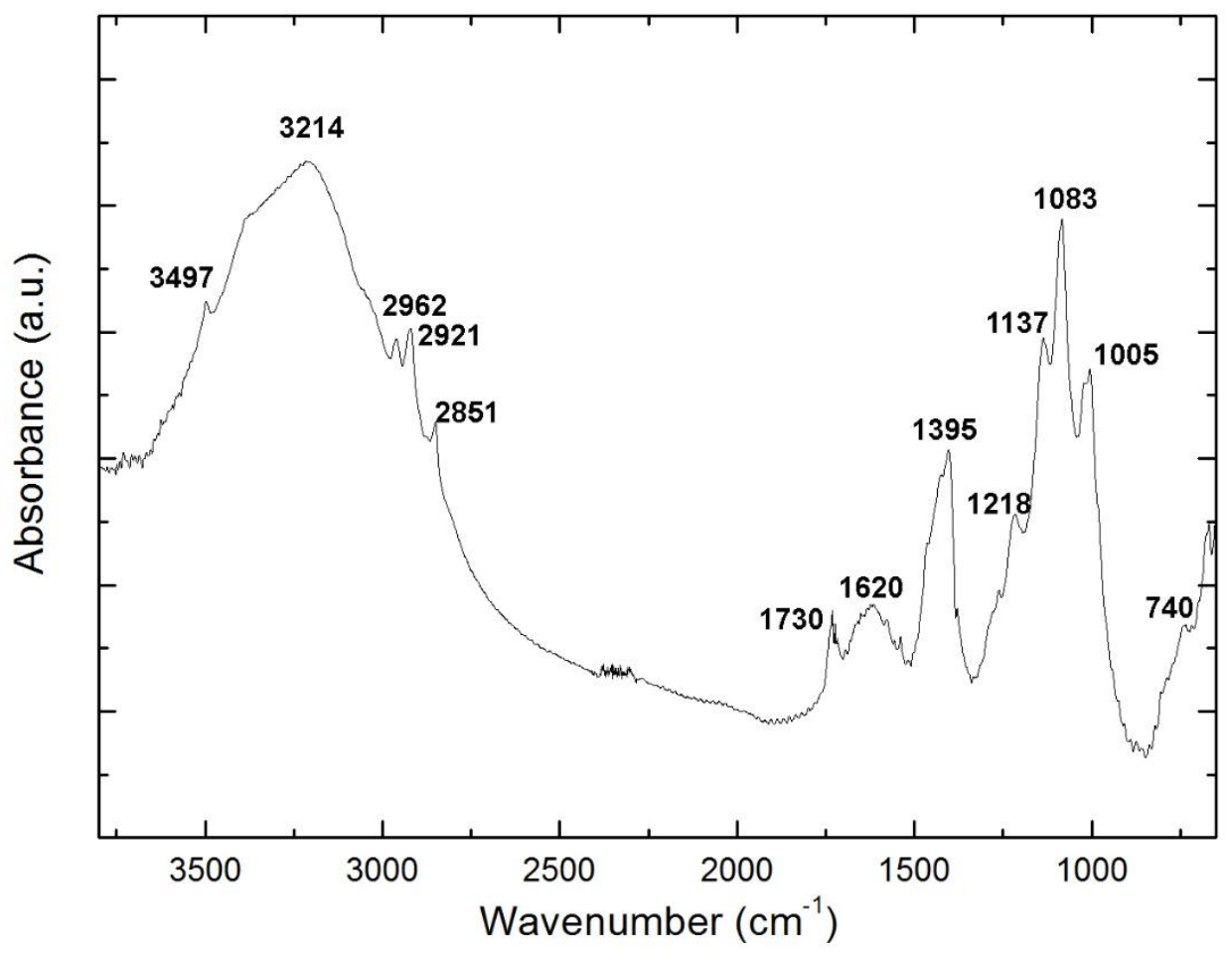

Figure 2. Infrared spectrum of acmonidesite. 


\section{Demartin et al.}

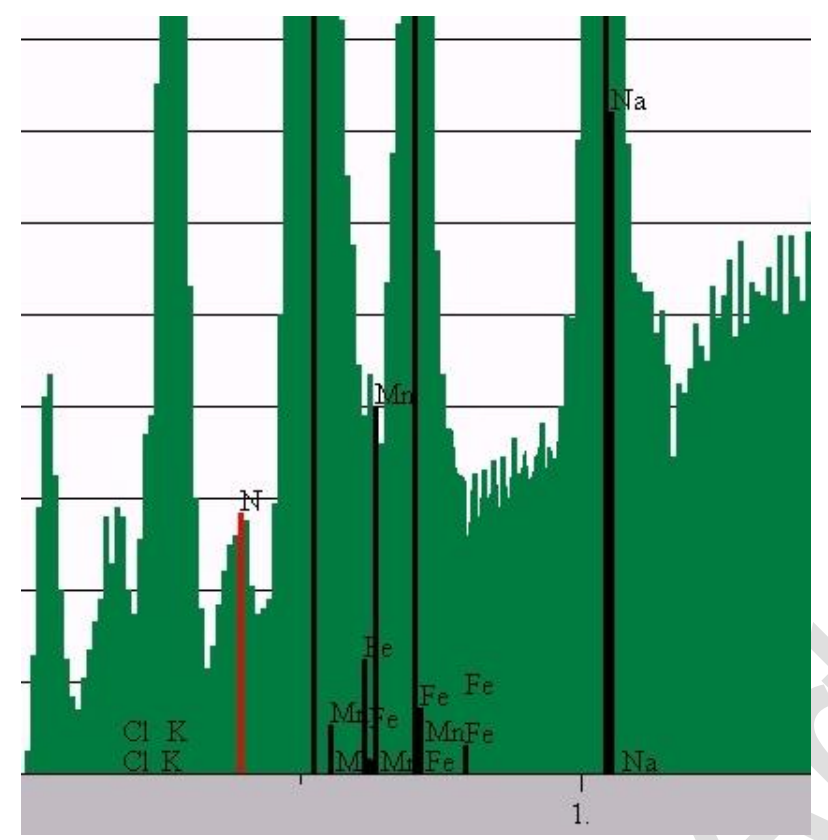

Figure 3. A portion of the EDS spectrum, where the presence of the ammonium nitrogen is evident.

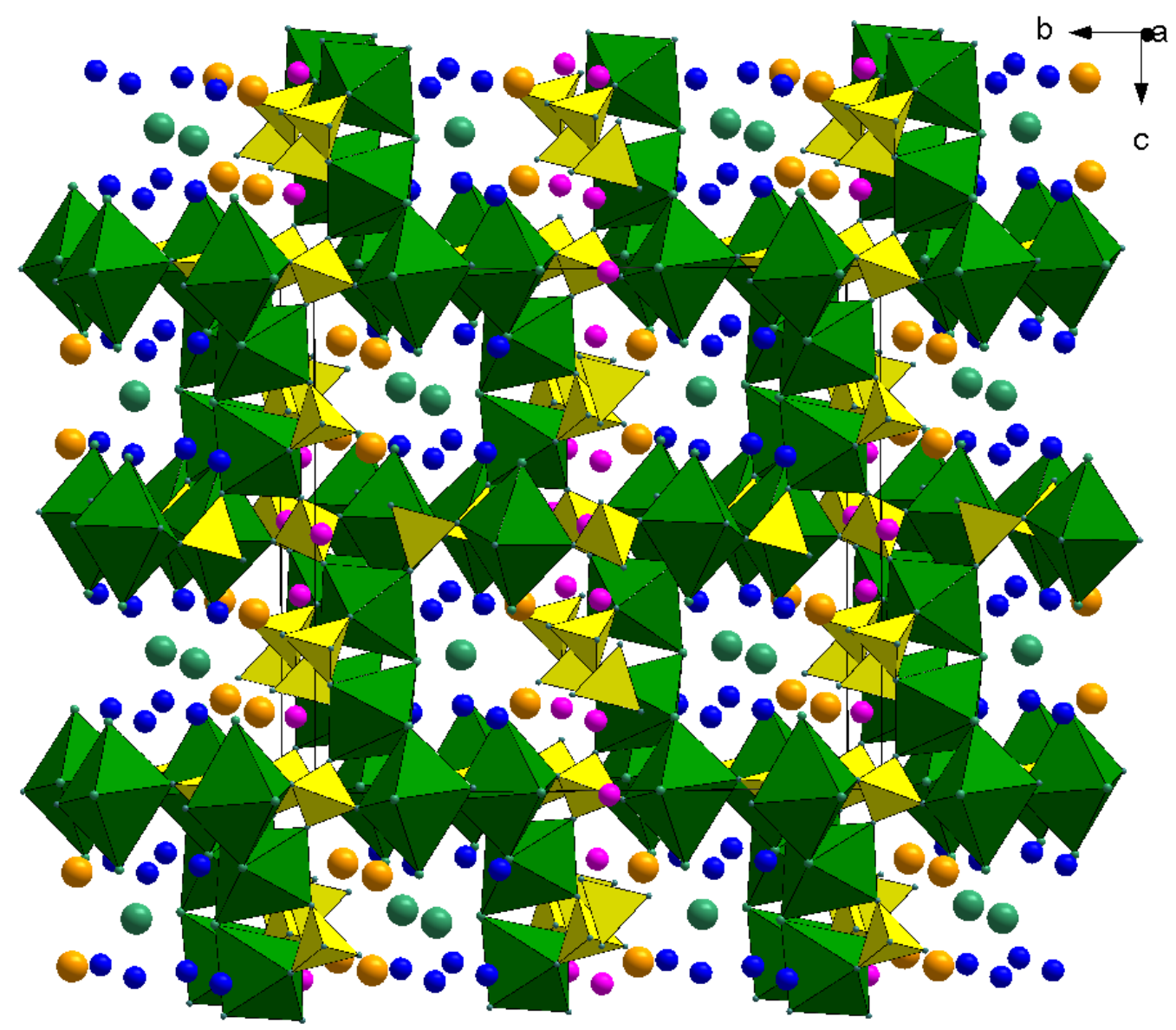

Figure 4. Perspective view of the structure of acmonidesite seen almost along [100]. $\mathrm{Fe}^{2+}$ : green octahedra; $\mathrm{SO}_{4}{ }^{2-}$ : yellow tetrahedra; $\mathrm{NH}_{4}{ }^{+}$: blue spheres; $\mathrm{Na}^{+} / \mathrm{Pb}^{2+}$ : orange spheres; $\mathrm{NH}_{4}{ }^{+} / \mathrm{K}^{+}$: magenta spheres; $\mathrm{Cl} 5$ : green spheres. 


\section{Demartin et al.}

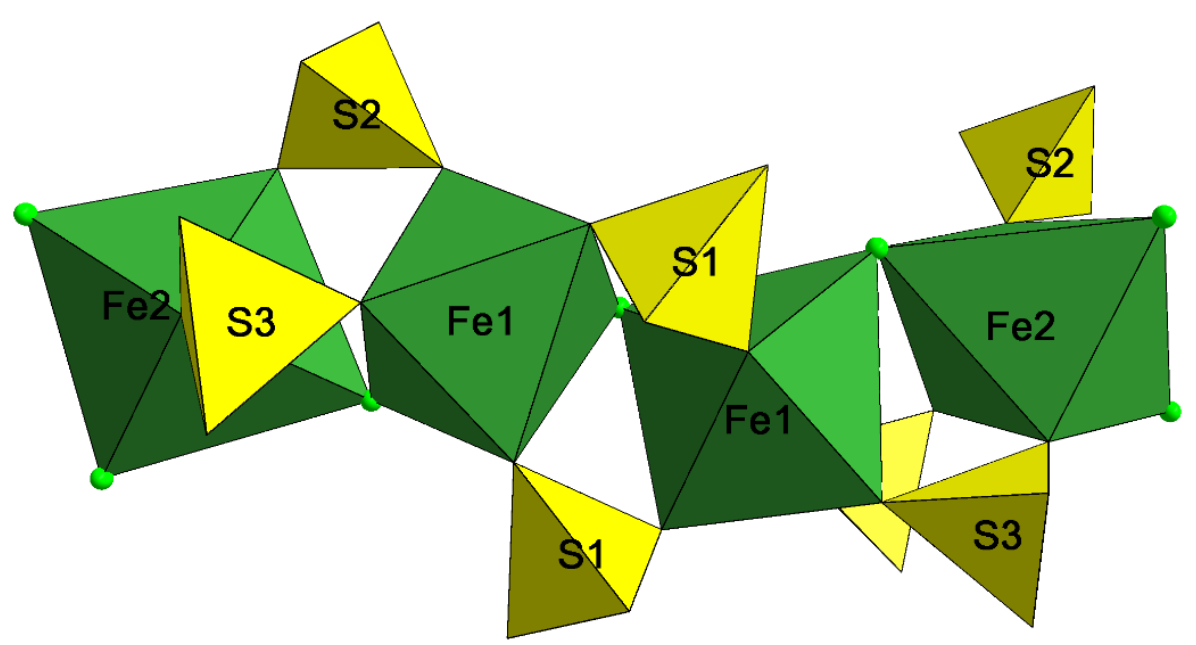

Figure 5. Perspective view of the discrete cluster of iron and sulfate polyhedra observed in acmonidesite.

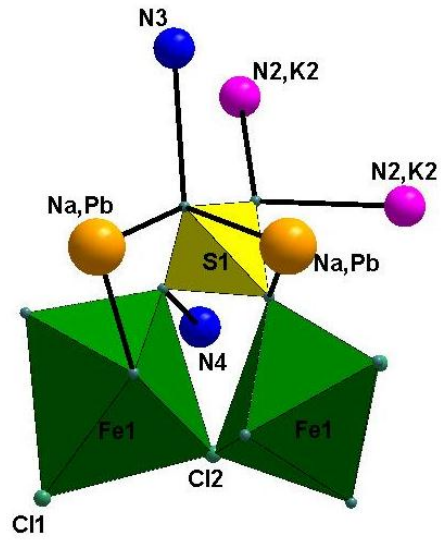

(a)

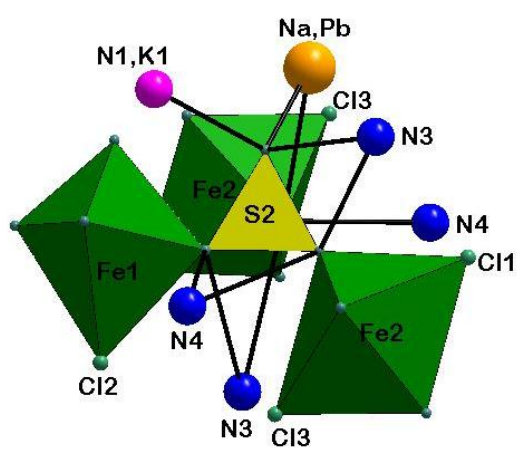

(b)

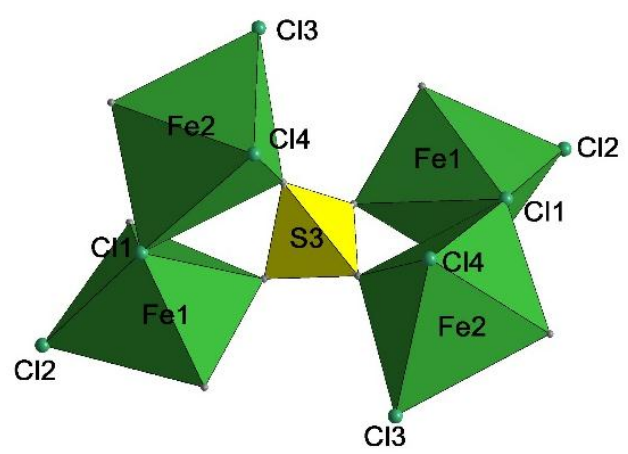

(c)

Figure 6. The environment about the three independent sulfate anions. 